\title{
Fenotip equol-producer dan hubungannya dengan asupan isoflavon dan kesehatan
}

\author{
Elly Herwana ${ }^{1}$
}

\begin{abstract}
ABSTRAK
Distribusi penyakit osteoporosis, penyakit kardiovaskuler, dan kanker yang berbeda antara populasi Asia dan Kaukasia membawa pemikiran atas keterkaitannya dengan perbedaan variasi diet antara kedua populasi. Studi epidemiologi menunjukkan asupan isoflavon kedelai pada populasi Asia jauh lebih tinggi daripada populasi Kaukasia. Isoflavon disebut sebagai fitoestrogen karena derivat isoflavon yaitu genistein, daidzein dan equol (metabolit daidzein) memiliki struktur molekul yang menyerupai estrogen dan dapat berikatan pada reseptor estrogen sebagai agonis lemah. Terikatnya derivat isoflavon dengan reseptor estrogen akan memberikan efek menyerupai estrogen (estrogen like effect). Berbagai hasil penelitian menunjukkan asupan dan suplementasi isoflavon berperanan pada penyakit yang didasari oleh defisiensi hormon estrogen antara lain mengurangi gejala premenopausal, menghambat osteoporosis, dan memberikan efek proteksi terhadap kanker payudara dan prostat. Di antara derivat isoflavon yang ada equol menunjukkan efek estrogenik yang lebih tinggi daripada derivat isoflavon lainnya. Kemampuan individu untuk memprodukasi equol tidak sama, sehingga individu dapat dibedakan sebagai fenotip equol-producer dan non-equolproducer. Hasil studi juga mengindikasikan adanya keterkaitan antara efek isoflavon dengan fenotip equol-producer.
\end{abstract}

Kata kunci: equol, daidzein, fenotip equol-producer, asupan isoflavon
${ }^{1}$ Departemen Farmakologi dan Farmasi Kedokteran, Fakultas Kedokteran Universitas Trisakti, Jakarta, Indonesia

\section{Korespondensi:}

Elly Herwana

Departemen Farmakologi dan Farmasi Kedokteran, Fakultas Kedokteran Universitas Trisakti, Jakarta, Indonesia Jalan Kyai Tapa Kampus B Grogol, 11440

Email: elly.herwana@trisakti.ac.id

J Biomedika Kesehat 2020;3(3):159165

DOI: 10.18051/JBiomedKes.2020. v3.159-165

pISSN: 2621-539X / eISSN: 2621-5470

Artikel akses terbuka (open access) ini didistribusikan di bawah lisensi Creative Commons Attribution 4.0 International (CC-BY 4.0) 
ABSTRACT

\section{Equol-producer phenotype and its relationship to soy isoflavone intake and health}

The prevalence of osteoporosis, cardiovascular disease, and cancer are different between Asia and Caucasia populations, suggesting an association with dietary variation between the two populations. Epidemiological studies have found that soy isoflavone intake in Asia populations is much higher than Caucasia populations. Isoflavones are called phytoestrogens because the isoflavon derivatives genistein, daidzein, and equol (a daidzein metabolite) have molecular structures that resemble the hormone estrogen, and thus exert estrogen-like properties and can bind as weak agonists to estrogen receptors. Studies have assessed the effects of soy protein and soy isoflavone in the pathophysiology of osteoporosis, cardiovascular diseases, and cancer. Supplementation with soy isoflavon is a potential alternative to hormone replacement therapy in postmenopausal women, which is administered to reduce menopausal symptoms and inhibit osteoporosis. Equol shows a higher estrogenic effect than other isoflavone derivatives. However, the ability of individuals to produce equol is not the same, so individuals distinguished as equol-producers and non-equol-producers phenotype. Recent studies indicate that there is an association between the equol-producer phenotype and the beneficial effects obtained from soy isoflavone consumption.

Keywords: equol, daidzein, equol-producer phenotype, isoflavone intake

\section{PENDAHULUAN}

Banyak komponen tanaman diidentifikasi mempunyai aktivitas biologis dan dimanfaatkan untuk obat, salah satunya adalah kedelai yang mengandung isoflavon. Makanan dengan bahan dasar kedelai banyak dikonsumsi oleh populasi di Asia, asupan isoflavon tertinggi didapatkan pada populasi Cina, Jepang, dan Korea. ${ }^{(1,2)}$ Beberapa studi yang dilakukan di Indonesia menunjukkan tingginya asupan isoflavon karena populasi Indonesia lebih banyak mengonsumsi makanan berbahan dasar kedelai seperti tahu, tempe, susu kedelai, dan kecap. ${ }^{(3-5)}$

Protein kedelai mengandung derivat isoflavon antara lain daidzein, genistein, dan glicitein. Struktur molekul derivat isoflavon maupun metabolitnya menunjukkan kemiripan struktur kimia dengan derivat estradiol (estrogen endogen). Bahan alam yang memiliki efek estrogenik disebut sebagai fitoestrogen. ${ }^{(6,7)}$ Studi in vitro menunjukkan bahwa isoflavon merupakan agonis lemah pada reseptor estrogen. Ada dua jenis reseptor estrogen yaitu $\operatorname{Er} \alpha$ dan $\operatorname{Er} \beta$, isoflavon menunjukkan afinitas yang lebih tinggi pada $\operatorname{Er} \beta$. (8)

Beberapa penelitian telah dilakukan untuk melihat efek fitoestrogen yang dimiliki isoflavon pada perempuan pascamenopause yang telah mengalami penurunan kadar estrogen. Osteoporosis pascamenopause yang ditandai dengan penurunan densitas tulang dan peningkatan risiko fraktur juga dikaitkan dengan rendahnya kadar erstrogen. Ada perbedaan insiden fraktur antar populasi dan jenis kelamin pada usia di atas 50 tahun. Proporsi risiko osteoporosis pada tiap populasi dan jenis kelamin perempuan $v s$ laki-laki adalah sebagai berikut; Amerika $(15.8 \%$ vs $6 \%$ ), Cina $(2.4 \%$ vs $1.9 \%)$, Hispanik $(8.5 \%$ vs 3.8\%). ${ }^{(9)}$ Rendahnya prevalensi osteoporosis pascamenopause pada perempuan pada populasi Asia dibandingkan dengan populasi Kaukasia dipercaya berhubungan dengan perbedaan asupan isoflavon kedelai antara kedua populasi..$^{(9,10)}$

Equol (7-hydroxy-3-(4'-hydroxyphenyl)chroman) adalah metabolit hasil metabolisme daidzein yang diproduksi melalui pembentukan intermediate-dihidrodaidzein oleh bakteri intestinal, di mana hanya sekitar $30-40 \%$ dari populasi dewasa yang memiliki kemampuan untuk menunjukkan transformasi ini pada uji pemberian kedelai. ${ }^{(7,11)}$ Efek estrogenik equol lebih tinggi dari daidzein maupun derivat isoflavon lainnya. (11) Kemampuan individu dalam memetabolisme daidzein menjadi equol tidak sama, sehingga individu dibedakan dalam dua kelompok yaitu fenotip equol-producers dan fenotip equol- nonproducers. $^{(11)}$

\section{Struktur kimia derivat isoflavon}

Isoflavon merupakan flavunoid yang terutama terdapat pada kacang kedelai (soy bean). Isoflavon utama pada kacang kedelai didapatkan sebagai sebagai glikosida yaitu genistein dan daidzein. Glikosida akan diubah sebagai aglikon yangaktifyaitugenistein(4'5,7-trihydroxyisoflavon, daidzein (4',7-dihydroxyisoflavon) dan glicitein (7,4'-dihydroxy6-methoxyisoflavon) dalam jumlah kecil. Isoflavon didapatkan pada kacang kedelai sebagai glikosida dan akan dikonversikan menjadi bentu aglikon di dalam makanan dengan bahan dasar kedelai. ${ }^{(1)}$ Equol [7-hydroxy-3-(49hydroxyphenyl)-chroman] adalah derivat isoflavon 
yang termasuk dalam klasifikasi komponen estrogen non-steroid.

Struktur molekul derivat isoflavon maupun metabolitnya (equol) menunjukkan kemiripan dengan derivat estrogen estradiol (Gambar 1). ${ }^{(12)}$ Gugus kimia yang terpenting dari derivat isoflavon adalah cincin fenolik yang merupakan binding site terhadap reseptor estrogen untuk memberikan efek estrogenik lemah, sehingga efek fitoestrogen yang dimiliki dapat merupakan agonis parsial atau antagonis. ${ }^{(12,13)}$ Aktivitas derivat isoflavon pada tingkat seluler dan molekuler dipengaruhi oleh banyak faktor seperti kadar isoflavon, status reseptor, ada atau tidaknya estrogen endogen, serta tipe dari organ dan sel target. ${ }^{(13)}$
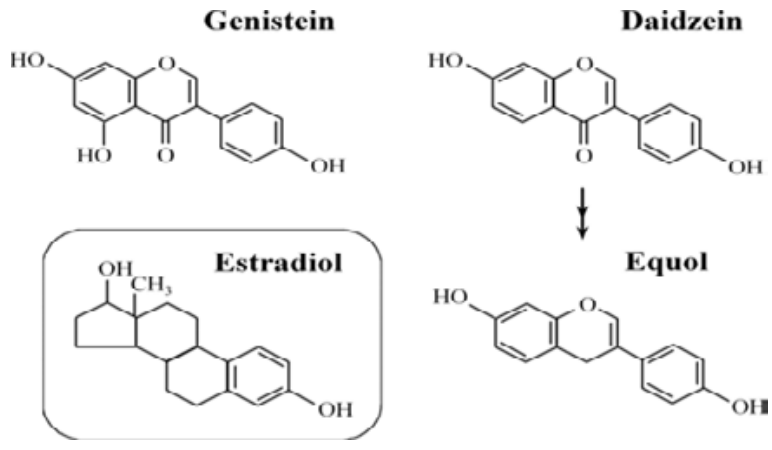

Gambar 1. Struktur molekul dirivat isoflavon ${ }^{(12)}$

\section{Asupan isoflavon dan fenotip equol-producer}

Soy isoflavone (isoflavon kedelai) berasal dari asupan makanan dengan bahan dasar kedelai. Isoflavon kedelai ini akan masuk ke dalam usus sebagai glikosida yang belum dapat diabsorpsi, Enzim intestinal $\beta$-hidroksilase bersama-sama dengan bakteria usus akan menghidrolisis glikosida menjadi bentuk aglikon. Bioaktif aglikon selanjutnya terkonjugasi selama dan setelah menembus barier usus dalam proses absorpsi. Bakteri usus akan melakukan dekonjugasi glukuronida dan diekskresikan ke empedu, sehingga meningkatkan ambilan kembali (reuptake) isoflavon. Selanjutnya mikroba spesifik dalam kolon akan berperan dalam reaksi transformasi ini. Genistein dapat dihidrolisis menjadi dihidrogenistein dan 6-hidroksi-O-desmetilangolensin atau asam 2,4,6-trihidroksibenzoat dan p-etill fenol. Daidzein dikoversi oleh mikroba usus menjadi dihidrodaidzein (DHD), equol, dan O-desmetillangolensin (O-DMA). Di sinilah peran penting dari bakteri usus yang turut menentukan kemampuan individu dalam metabolime daidzein untuk memproduksi equol dan membedakannya sebagai fenotip equol producer dan equol nonproducer. ${ }^{(12,13)}$

Selain dari bakteri usus, yang juga berperan adalah faktor diet, termasuk asupan isoflavon sendiri. Pola asupan makronutrien (misalnya: isoflavon, tinggi karbohidrat, serat, dan lemak) dapat berkaitan dengan kemampuan untuk memproduksi equol. Vegetarian menunjukkan prevalensi fenotip equol producer yang lebih tinggi daripada non-vegetarian (59\% vs 25\%)..(12) Makronutrien berhubungan bermakna dengan perubahan mikrobiota feses yang dominan sehingga meningkatkan persentase mikroorganisme. ${ }^{(13-15)}$

Prevalensi equol-producer pada populasi Kaukasia dengan asupan isoflavon yang rendah adalah $20-35 \%$ sementara prevalensinya pada populasi Asia didapatkan lebih tinggi yaitu 50$55 \%{ }^{(16)}$ Rerata asupan isoflavon kedelai pada populasi Asia bervariasi antara $25-50 \mathrm{mg} / \mathrm{hari}$ dan nilai ini jauh lebih tinggi dibandingkan dengan asupan pada populasi Kausasia yaitu sebesar $2 \mathrm{mg}$ / hari. ${ }^{(6)}$ Studi lain melaporkan bahwa suplementasi isoflavon selama 3 hari pada populasi Korea dan Amerika menunjukkan prevalensi fenotip equolproducer yang berbeda bermakna yaitu 51\% pada populasi Korea dan $36 \%$ pada populasi Kaukasia. (17) Penelitian lainnya mendapatkan adanya perbedaan farmakokinetik dan bioavailabilitas antara populasi Asia dan Kaukasia. ${ }^{(18)}$ Populasi Asia memperlihatkan kemampuan absorpsi isoflavon kedelai yang lebih tinggi dan peningkatan area di bawah kurva kadar plasma terhadap waktu (area under curve $=\mathrm{AUC}$ ) dan kadar plasma maksimal (Cmax) untuk daidzein dan genistein. Selain itu, studi lainnya melaporkan bahwa asupan isoflavon kedelai selama 3 hari meningkatkan frekuensi fenotip equol-producer dari $26.8 \%$ menjadi $60.4 \%$ pada populasi Cina. ${ }^{(16)}$ Penelitian yang dilakukan pada populasi Indonesia menunjukkan asupan isoflavon kedelai yang tinggi $(>150 \mathrm{mg} /$ hari) ${ }^{(3-5)}$ serta proporsi equol-producer yang tinggi yaitu $69.2 \%$ pada perempuan pascamenopause dengan osteopenia di mana suplementasi $100 \mathrm{mg}$ isoflavon kedelai selama 3 bulan meningkatkan proporsi equol-producer. ${ }^{(19)}$ Hasil studi lainnya juga menunjukkan asupan isolavon dapat 
meningkatkan frekuensi equol-producer, yang berarti dapat mengubah fenotip equol-nonproducer menjadi fenotip equol-producer. ${ }^{(19)}$ Kemampuan individu memetabolisme daidzein menjadi equol kemungkinan juga dipengaruhi faktor genetik dalam kaitannya terhadap perkembangan dan pengendalian bakteri usus. ${ }^{(20)}$

\section{Efek isoflavon pada kesehatan}

Efek manfaat atas konsumsi makanan berbahan dasar kedelai atau suplementasi isoflavon terhadap kesehatan serta keterkaitannya dengan equol telah diteliti secara luas. Isoflavon menunjukkan implikasi protektif pada osteoporosis, penyakit kardiovaskular, dan kanker, terutama kanker payudara dan prostat. ${ }^{(1)}$ Equol merupakan komponen unik yang menyerupai struktur kimia estradiol (estrogen endogen). Molekul kimia yang mirip ini dapat memberikan efek estrogenik, dan sekaligus menjadi antagonis kuat untuk dihidrotestosteron. Study in vitro dan in vivo menunjukkan bahwa equol mempunyai aktivitas biologis yang lebih tinggi daripada daidzein. ${ }^{(20)}$ Equol mempunyai afinitas yang lebih tinggi terhadap reseptor estrogen $(\operatorname{Er} \beta)$ dan lebih poten dalam efek estrogenik maupun aktivitas sebagai antioksidan. ${ }^{(20)}$

\section{Isoflavon dan kesehatan tulang}

Menopause merupakan kondisi fisiologis yang ditandai dengan henti haid disertai penurunan kadar hormon estrogen. Deplesi estrogen pascamenopause membawa dampak percepatan terjadinya osteoporosis disertai peningkatan risiko terjadinya fraktur. ${ }^{(10,21)}$ Osteoporosis adalah penyakit dengan karakteristik massa tulang yang rendah dan kerusakan mikroarsitektur jaringan tulang, membuat tulang menjadi rapuh dan mudah patah sehingga membutuhkan penatalaksanaan yang efektif untuk mencegah terjadinya fraktur. Terapi sulih hormon dengan pemberian estrogen sintetik atau selective estrogen receptor modulator (SERM) merupakan pilihan yang telah dibuktikan efektif untuk mengatasi osteoporosis pascamenopause. ${ }^{(21)}$ Pemberian estrogen sintetik potensial menyebabkan efek samping berupa peningkatan risiko keganasan payudara dan penyakit kardiovaskular sehingga memiliki keterbatasan dalam indikasinya. ${ }^{(22)}$

Isoflavon memiliki rumus kimia yang menyerupai estradiol sehingga dapat berikatan dengan reseptor estrogen (ER $\beta$ ) sehingga memberikan estrogen-like effect. ${ }^{(8)}$ Beberapa studi telah dilakukan untuk melihat efektivitas isoflavon terhadap osteoporosis. Terdapat studi komparatif antara efektivitas isoflavon kedelai dibandingkan dengan terapi sulih hormon untuk mencegah osteoporosis pada perempuan pascamenopause, hasil studi menunjukkan bahwa kedua jenis terapi memberikan efek yang bermanfaat pada bone mineral density (BMD) dan menghambat resorpsi tulang. ${ }^{(21)}$ Sebaliknya hasil studi lainnya menunjukkan adanya korelasi antara kadar estrogen dan indeks massa tubuh dengan BMD, namun tidak ada korelasi antara asupan isoflavon dengan BMD. ${ }^{(22)}$ Hasil studi lainnya menunjukkan bahwa suplementasi isoflavon kedelai mempunyai tendensi meningkatkan BMD dan penanda resorpsi tulang (bone resorption marker). ${ }^{(23)}$ Studi metaanalisis juga menunjukkan bahwa suplementasi ekstrak isoflavon kedelai meningkatkan makna BMD pada tulang belakang, tetapi tidak bermakna untuk kolum femoris, panggul, dan trokanter pada perempuan pascamenopause. ${ }^{(24)}$ Studi metaanalisis lainnya menunjukkan suplementasi isoflavon kedelai meningkatkan BMD dan menurunkan resorpsi tulang dibandingkan pengukuran awal sebelum suplementasi diberikan secara bermakna. ${ }^{(25)}$ Banyak studi telah dilakukan untuk menilai efek isoflavon pada tulang dengan menggunakan BMD, penanda resorpsi tulang, atau insiden terjadinya fraktur, dengan dosis yang bervariasi. Tetapi efektivitas isoflavon kedelai untuk terapi osteoporosis tetap menunjukkan hasil yang tidak konklusif. Efek isoflavon yang bermakna untuk BMD maupun penanda tulang adalah relatif, dipengaruhi oleh status menopause, tipe suplementasi, dosis dan lama pemberian isoflavon.

\section{Isoflavon dan penyakit kardiovaskuler}

Penyakit kardiovaskular (cardiovascular disease $=$ CVD) adalah salah satu penyebab kematian tertinggi pada laki-laki maupun perempuan. Perempuan premenopause menunjukkan prevalensi CVD yang lebih rendah dibandingkan laki-laki dan estrogen dipercaya sebagai hormon yang bersifat kardioprotektif. Risiko CVD meningkat setelah menopause dan penurunan kadar estrogen dianggap berperan 
pada fungsi endotel, tonus vaskuler, profil lipid, dan fungsi jantung. Estradiol (17-beta-estradiol) adalah hormon estrogen endogen yang terutama disintesis dan disekresikan oleh overium, kadarnya berkurang akibat penurunan fungsi ovarium pascamenopause. Estradiol berikatan pada kedua reseptor estrogen, $E R \alpha$ dan $\operatorname{Er} \beta$ dan mengaktivasi transkripsi intraseluler yang diekspresikan pada sel endotel vaskuler, otot polos vaskuler, dan sel otot jantung, sehingga menghasilkan efek kardioprotektif pada perempuan premenopause. $(26,27)$

Pemberian terapi sulih estrogen pada perempuan pascamenopause menuai kontroversi karena disamping manfaatnya menggantikan fungsi estrogen yang menurun, juga memberikan efek samping peningkatan risiko keganasan payudara sehingga membatasi indikasinya. Penelitian dari Women's Health Initiative (WHI) mengenai terapi hormon menetapkan manfaat dan risiko terapi sulih hormon pada perempuan pascamenopause. Pemberian estrogen diduga kuat memberikan keuntungan secara menyeluruh, tetapi miningkatkan pula efek yang merugikan pada penggunaan jangka panjang. ${ }^{(28,29)}$

Derivat isoflavon (genistein, daidzein) dan metabolitnya (equol) memiliki struktur molekul menyerupai estradiol banyak diteliti untuk menilai efeknya pada kardiovaskular. Banyak penelitian telah dilakukan untuk mengevaluasi efek isoflavon pada CVD, sebagian besar penelitian menilai perubahan profil lipid yang berperan penting pada proses arterosklerosis yang mendasari CVD seperti hipertensi, iskemia jantung hingga miocard infark. Terdapat studi yang melaporkan bahwa suplementasi protein kedelai maupun isoflavon kedelai, keduanya memberikan efek perubahan profil lipid, pemberian protein kedelai dapat menurunkan kadar kolesterol, low density lipoprotein (LDL), trigliserida, indeks aterogenik, dan meningkatkan high density lipoprotein (HDL), sementara isoflavon hanya bermakna dalam menurunkan kadar trigliserida. ${ }^{(30)}$ Studi lain menunjukkan suplementasi isoflavon kedelai (daidzein) selama 6 bulan menurunkan kadar LDL. (31) Asupan isoflavon (daiszein) yang lebih tinggi menurunkan kadar kolesterol..$^{(3)}$ Subjek dengan fenotip equol-producer menunjukkan tendensi kadar HDL yang lebih tinggi, karena daidzein dan equol yang menunjukkan pengaruh lebih tinggi terhadap profil lipid. ${ }^{(32)}$

\section{Isoflavon dan kanker}

Kanker adalah penyakit yang memiliki fatalty rate lebih tinggi di antara penyakit lain dan kanker payudara menunjukkan insidens paling tinggi di antara jenis kanker yang terjadi pada perempuan. Prevelensi kanker payudara menunjukkan perbedaan yang besar antara populasi Kaukasia dan Asia, Hispanik, dan perempuan Afrika. Populasi Kaukasia menempati prevalensi tertinggi sementara Asia yang paling rendah, sehingga membawa pemikiran bahwa faktor diet berperan penting atas perbedaan ini. Beberapa hasil studi menunjukkan bahwa asupan isoflavon dalam makanan berbahan dasar kedelai menurunkan risiko dan mortalitas kanker payudara. ${ }^{(33)}$

Isoflavon yang mempunyai kemiripan struktur molekul estradiol, dapat berikatan sebagai agonis lemah pada reseptor estrogen, sehingga melemahkan efek estrogen endogen. Terdapat hasil penelitian yang menunjukkan perempuan dengan asupan isoflavon yang lebih tinggi berhubungan dengan penurunan risiko kanker payudara pada perempuan pascamenopause. ${ }^{(34)}$ Makanan berbahan dasar kedelai menjadi sumber utama isoflavon dari diet, terutama mengandung genistein dan daidzein. Equol, metabolit derivat isoflavon daidzein, menunjukkan afinitas yang lebih tinggi pada $\operatorname{Er} \beta$ dibandingkan daidzein.( ${ }^{(2)}$ Penelitian lainnya melaporkan bahwa pada asupan isoflavon yang rendah, fenotip equol-producer tidak berhubungan dengan risiko kanker. ${ }^{(35)}$ Daidzein paling banyak dilaporkan untuk efek isoflavon dan equol sebagai metabolit daidzein dilaporkan memberikan efek yang lebih tinggi. Modulasi jalur sinyal efek manfaat isoflavon terhadap kanker payudara belum dapat dipahami sepenuhnya. Hasil temuan dari beberapa studi melaporkan adanya indikasi yang kuat bahwa isoflavon meningkatkan prognosis pasien kanker. Implementasi pemberian diet isoflavon pada penderita kanker payudara juga masih menuai kontroversi, terutama atas efek ganda isoflavon sebagai efek estrogenik dan anti-estrogenik. ${ }^{(36)}$ Hasil studi meta-analisis melaporkan bahwa pada populasi Asia, asupan isoflavon kedelai potensial menurunkan risiko kanker payudara pada perempuan premenopause maupun pascamenopase, sementara pada populasi 
Kaukasia tidak diperoleh bukti yang mendukung hubungan antara asupan isoflavon dan kanker payudara. ${ }^{(37)}$

Kanker prostat adalah salah satu jenis kanker yang paling banyak dijumpai pada laki-laki. Penyakit kanker ini bersifat hormone-dependent yang progresivitasnya dikendalikan oleh hormon adrogen. Efek isoflavon untuk menghambat perkembangan kanker prostat dimediasi oleh hormone-like effects melalui competitive binding estrogen receptors (Er $\alpha$ dan ER $\beta$ ). Studi epidemiologi memperlihatkan bahwa insiden dan mortalitas yang rendah untuk kanker prostat pada populasi Asia, sehingga diduga bahwa variasi diet berkaitan erat dengan prevalensi kanker prostat. ${ }^{(38)}$

Asupan makanan berbahan dasar kedelai (genistein dan daidzein) berhubungan dengan kanker prostat karena estrogen berperan sebagai umpan balik (feedback) sekresi androgen endogen. Asupan isoflavon kedelai berbanding terbalik dengan risiko kanker prostat. Genistein potensial untuk memodulasi ekspresi biomarker jaringan prostat, sehingga bermanfaat untuk efek pencegahan kanker prostat. Isoflavons kedelai menunjukkan mekanisme aksi yang multipel, melalui efek antioksidan dan anti-inflamasi, dapat bermanfaat mengurangi reaksi efek samping pemberian obat antikanker dan radiasi. ${ }^{(39)}$ Hasil penelitian terdahulu mendapatkan bahwa asupan isoflavon kedelai (genistein dan daidzein) menunjukkan tendensi penurunan risiko kanker prostat, meskipun asosiasi antara risiko kanker prostat, asupan isoflavon, kadar genistein dan daidzein dalam serum belum sepenuhnya terbukti. (40)

\section{KESIMPULAN}

Banyak studi telah dilakukan untuk menilai efek isoflavon pada kesehatan manusia. Hasil studi in vitro membuktikan bahwa genistein, daidzein, dan equol berikatan dengan kedua tipe reseptor estrogen, tetapi bukti klinis tidak memberikan hasil yang sesuai dengan prediksi. Penelitian untuk menilai efek isoflavon yang berasal dari asupan maupun suplementasi protein kedelai tehadap berbagai penyakit, memberikan bukti yang bervariasi karena banyak faktor yang mempengaruhi hasil studi. Perbedaan farmakokinetik antarindividu, fenotip equolproducer, dosis pemberian yang bervariasi, perbedaan variasi diet, membuat berbagai hasil penelitian mengenai efektivitas isoflavon terhadap berbagai penyakit tidak dapat disimpulkan secara konklusif. Sejauh ini, berbagai penelitian mengenai isoflavon tidak melaporkan tentang efek samping yang berbahaya, sehingga penggunaan isoflavon dipercaya memberikan manfaat untuk kesehatan dan sebagai ajuvan untuk pengobatan dan pencegahan penyakit yang berkaitan dengan hormon estrogen.

\section{REFERENSI}

1. Nagata C. Factors to Consider in the Association Between Soy Isoflavon Intake and Breast Cancer Risk. J Epidemiol 2010;20:83-9. doi:10.2188/jea. JE2009018.

2. Messina $\mathrm{M}$, Nagata $\mathrm{C}$, Wu AH. Estimated Asia Adult Soy Protein and Isoflavon Intakes. Nutr Cancer 2006;55:1-12. doi: 10.1207/ s15327914nc5501 1 .

3. Herwana E, Puspāini, Graciela A. High dietary daidzein intake lowers cholesterol levels among post-menopausal women. Univ Med. 2020;38:4754. doi:10.18051/UnivMed.2020.v39.47-54.

4. Pusparini, Dharma R, Suyatna FD, etal.Effect of soy isoflavone supplementation on vascular endothelial function and oxidative stress in postmenopausal women: a community randomized controlled trial. Asia Pac J Clin Nutr. 2013;22(3):357-64. doi: 10.6133/apjen.2013.22.3.13

5. Wratsangka R. Soy isoflavone supplementation tends to improve specific immune responses in postmenopausal women. Univ Med 2011;30:16272. doi: 10.18051/UnivMed.2011.v30.162-172

6. Messina M. Soy foods, isoflavones, and the health of postmenopausal women. Am J Clin Nutr. 2014 Jul;100 Suppl 1:423S-30S. doi: 10.3945/ ajcn.113.071464

7. Wang Q, Ge X, Tian X, et al. Soy isoflavon: The multipurpose phytochemical (Review). Biochemical Reports 2013;1: 697-70. doi: 10.3892/br.2013.129.

8. Iorga A, Cunningham CM, Moazeni S, et al. The protective role of estrogen and estrogen receptors in cardiovascular disease and the controversial use of estrogen therapy. Biol Sex Differ 2017;8:33. 16 pages. doi: 10.1186/s13293-017-0152-8.

9. Cauley JA. Defining Ethnic and Racial Differences in Osteoporosis and Fragility Fractures. Clin Orthop Relat Res 2011;469:1891-99. doi: 10.1007/ s11999-011-1863-5.

10. Cong E, Walker MD. The Chinese skeleton: insights into microstructure that help to explain the epidemiology of fracture. Bone Res. 2014;2:14009. doi:10.1038/boneres.2014.9.

11. Setchell KDR, Cole SJ. Method of Defining Equol-Producer Status and Its Frequency among Vegetarians. J Nutr 2006;136: 2188-93.

12. Wood CE, Appt SE, Clarkson TB, et al. Effect of high-dose soy isoflavons and equol on reproductive tissues in female cynomolgus monkeys. Biol Reprod. 2006;75:477-86.

13. Blaut M, Clavel T. Metabolic Diversity of the Intestinal Microbiota: Implications for Health and Disease. J Nutr. 2007;137: 751S-5S, 2007. 
doi:10.1093/jn/137.3.751S

14. Bolca E, Possemiers S, Herregat A, et al. Microbial and Dietary Factors Are Associated with the Equol Producer Phenotype in Healthy Postmenopausal Women. Nutr. 2007;137: 2242-46.

15. Clavel T, Neto JCG, Lagkouvardos I, et al. Deciphering interactions between the gut microbiota and the immune system via microbial cultivation and minimal microbiomes. Immunol Rev. 2017;279: 8-22. doi:10.1111/imr.12578.

16. Liu B, Qin L, Liu A, et al. Prevalence of the EquolProducer Phenotype and Its Relationship with Dietary Isoflavon and Serum Lipids in Healthy Chinese Adults. J Epidemiol 2010;20:377-84. doi:10.2188/jea.JE20090185.

17. Song KB, Atkinson C, Frankenfeld CL, et al. Prevalence of Daidzein-Metabolizing Phenotypes Differs between CaucAsia and Korean American Women and Girls. J Nutr 2006;136: 1347-51. doi: $10.1093 /$ jn/136.5.1347.

18. Vergne S, Sauvant P, Lamothe V, et al. Influence of ethnic otigin (Asia v. CaucAsia) and background diet on the bioavailability of dietary isoflavons. Br J Nutr 2009;102:1642-53. doi: 10.1017/ S0007114509990833.

19. Herwana E, Setiabudy R, Soegondo S, et al. Soy isoflavon supplementation increases equolproducing capability in postmenopausal women with osteopenia. Univ Med 2012;31:120-30.

20. Hong KW, Ko KP, Ahn Y, et al. Epidemiological profiles between equol producers and nonproducers: a genomewide association study of the equol-producing phenotype. Genes Nutr. 2012;7:567-74. doi: 10.1007/s12263-012-0292-8.

21. Tit DM, Bungau S, Iovan $\mathrm{C}$, et al. Effects of the Hormone Replacement Therapy and of Soy Isoflavons on Bone Resorption in Postmenopause. J. Clin. Med. 2018;7:297. doi:10.3390/ jcm7100297.

22. Nagata C, Shimizu H, Takami R, et al. Soy product intake and serum isoflavonoid and estradiol concentration in relation to bone mineral density in postmenopausal Japanese women. Osteoporos Int. 2002:13;200-04.

23. Tai TY, Tsai KS, Tu ST, et al. The effect of soy isoflavon on bone mineral density in postmenopausal Taiwanese women with bone loss: a 2-year randomized double-blind placebocontrolled study. Osteoporos Int. 2012; 23:157180. doi: 10.1007/s00198-011-1750-7.

24. Taku K, Melby MK, Takebayashi J, et al. Effect of soy isoflavon extract supplements on bone mineral density in menopausal women: meta-analysis of randomized controlled trials. Asia Pac J Clin Nutr. 2010;19:33-42.

25. Wei P, Liu M, Chen Y, et al. Systematic review of soy isoflavon supplements on osteoporosis in women. Asia Pacific Journal of Tropical Medicine 2012;2:243-8.

26. Newson L. Menopause and cardiovascular disease. Post reproductive health 2018;24:44-9. doi: $10.1177 / 2053369117749675$.

27. Ueda K, Adachi Y, Fukuma N, et al. Regulatory actions of estrogen receptor signaling in the cardiovascular system. Front endocrinol 2020;10. Article 10:909. doi: 10.3389/fendo.2019.00909.

28. Roehm E. A reappraisal of Women's Health Initiativie Estrogen-alone trial: Long term outcomes in women 50-59 years of age. Int J Gynaecol Obstet 2015, Article ID 713295, 10 pages. doi: 10.1155/2015/713295.

29. Lorga A, Cunningham CM, Moazeni S, et al. The protective role of estrogen and estrogen receptors in cardiovascular disease and the controversial use of estrogen therapy. Biol Sex Differ 2017;8:33, 16 pages. doi: 10.1186/s13293-017-0152-8.

30. Jassi HK, Jain A, Arora S, et al. Effect of soy protein Vs soy isoflavons on lipid profile in postmenopausal women. Indian J Clin Biochem 2010;25:201-7.

31. Yenny, Pusparini. Isoflavon supplementation reduces low-density lipoprotein cholesterol levels in postmenopausal women. Univ Med 2013;32:197-207.

32. Guo K, Zhang B, Chen C, et al. Daidzeinmetabolizing phenotypes in relation to serum lipids and uric acid in adults in Guangzhou, China. Br J Nutr 2010;104:118-24. doi: 10.1017/ S0007114510000279.

33. He FJ, Chen JQ. Consumption of soybean, soy foods, soy isoflavons and breast cancer incidence: Differences between Chinese women and women in Western countries and possible mechanisms. Food Science and Human Wellness 2013;2:14616. doi:10.1016/j.fshw.2013.08.002.

34. Wada K, Nakamura K, Tamai Y, et al. Soy isoflavon intake and breast cancer risk in Japan: From the Takayama study. Int. J. Cancer 2013;133: 952-960.

35. Virk-Baker MK, Barnes S, Krontiras H, et al. S-(-) equol producing status not associated with breast cancer risk among low isoflavon consuming US postmenopausal women undergoing a physician recommended breast biopsy. Nutr Res. 2014; 34 : 116-25. doi:10.1016/j.nutres.2013.12.002.

36. Ziaei S, Halaby R. Dietary Isoflavons and Breast Cancer Risk. Medicines 2017, 4, 18; doi:10.3390/ medicines4020018

37. Chen M, Rao Y, Zheng Y, et al. Association between Soy Isoflavon Intake and Breast Cancer Risk for Pre- and Post-Menopausal Women: A Meta-Analysis of Epidemiological Studies. PLOS ONE 2014;20;9(2):e89288. doi: 10.1371/journal. pone.0089288.

38. Sivoňová MK, Kaplán $\mathrm{P}$, Tatarková $\mathrm{Z}$, et al. Androgen receptor and soy isoflavons in prostate cancer (Review). Mol Clin Oncol 2018;10:191204. doi: 10.3892/mco.2018.1792.

39. Sahin I, Bilir B, Ali S, et al. Soy Isoflavons in Integrative Oncology: Increased Efficacy and Decreased Toxicity of Cancer Therapy. Integr Cancer Ther 2019;18:1-11. doi: $10.1177 \% 2$ F 1534735419835310.

40. He J ,Wang S, Zhou M, et al. Phytoestrogens and risk of prostate cancer: a meta-analysis of observational studies. World J Surg Oncol 2015;13:146-61. doi: 10.1186/s12957-015-06489. 